\title{
Üniversitelerin Yerel Ekonomiye Etkileri: Bursa Uludağ Üniversitesi Örneği
}

\author{
Volkan Gursel $^{\mathrm{a}}$, Cem Okan Tuncel ${ }^{\mathrm{b}}$, Serdar Geldimyradov ${ }^{\mathrm{c}}$
}

Öz: Üniversiteler, bulundukları kentin yalnızca toplumsal ve kültürel gelişimini değil ekonomik gelişimini de olumlu etkilemektedirler. Bulundukları kentlerde, özellikle öğrenci harcamaları sayesinde kentin ekonomik büyümesine katkı sağlamaktadırlar. Bu çalışmanın amacı, Bursa Uludağ Üniversitesi'nin Bursa ekonomisi üzerindeki doğrudan, dolayı ve uyarılmış etkilerini araştırmaktır. Çalışmada, üniversitenin harcama birimlerinden derlenen bilgiler ve ögrenci harcamalarını hesaplamak üzere üniversitenin kent merkezindeki yerleşkelerde öğrenim gören 381 öğrenciye uygulanan anket sonucu elde edilen veriler kullanılmıştır. Verilerin analiz sonuçlarına göre, Bursa Uludağ Üniversitesi 2018 yılında Bursa ekonomisine toplam 1,21 milyar TL doğrudan ve dolaylı gelir, 13.870 kişilik doğrudan ve dolaylı istihdam katkısı sağlamıştır. Sonuç olarak, Bursa Uludağ Üniversitesi'nin kent ekonomisi üzerindeki uyarılmış gelir etkisi 2,57 milyar TL, uyarılmış istihdam etkisi ise 21.227 çalışan olarak tahmin edilmiştir.

\section{The Effects of Universities on Local Economy: The Case Study of Bursa Uludag University}

Abstract: Universities have a positive influence on the cities not only in terms of cultural and social aspects but also in economic aspects. Due to students' expenditures, universities make a contribution to urban economic growth in the cities where they located. The main goal of this study is to investigate the direct, indirect, and induced effects of Bursa Uludag University on the Bursa economy. In this study, the information compiled from spending units of the university, and data gathering from 381 students of Bursa Uludag University are used. According to data analyzing results, Bursa Uludag University created a total of 1.21 billion Turkish Lira (TL) direct and indirect income, and 13,870 direct and indirect employment in the Bursa economy in 2018. As a result, induced income effect and induced employment effect of Bursa Uludag University are estimated as 2.57 billion TL and 21,227 employees respectively.

Anahtar Sözcükler: Kent Ekonomisi, Bursa Ekonomisi, Üniversite, Öğrenci Harcamaları, Ekonomik Etki

JEL: 123,010

$\begin{array}{ll}\begin{array}{l}\text { Geliş } \\ \text { Düzeltme }\end{array} & : 11 \text { Aralık } 2020 \\ \text { Kabul } & : 17 \text { Şubat } 2021 \\ & : \text { 09 Temmuz } 2021 \\ \text { Tür } & : \text { Araştırma }\end{array}$

Keywords: Urban Economy, Bursa Economy, University, Students' Expenditure, Economic Impact

JEL: 123,010

Received : 11 December 2020 Revised : 17 February 2021

Accepted : 09 July 2021

Type : Research

\footnotetext{
a Res. Asst., PhD., Bursa Uludag University, Faculty of Economics and Administrative Sciences, Department of Economics, Bursa, Turkiye, vgursel@uludag.edu.tr (ORCID ID: 0000-0003-4942-9978)

b Assoc. Prof., PhD., Bursa Uludag University, Faculty of Economics and Administrative Sciences, Department of Economics, Bursa, Turkiye, cotuncel@uludag.edu.tr (ORCID ID: 0000-0002-7073-8506)

Bursa, Turkiye, serdargm1994@gmail.com (ORCID ID: 0000-0002-5119-9676)
} 


\section{Giriş}

Bilginin ticarileştiği ve ülkeler arası rekabetin bilgiye dayalı olduğu günümüz dünyasında üniversitelerin önemi daha da artmaktadır. Üniversiteler, toplumun her kademesine doğrudan veya dolaylı olarak etki etmektedir. Üniversiteler, bireysel faydaların yanı sıra toplumsal ve ekonomik faydalar sağlamaktadır. Bireysel faydaların toplumsal ve ekonomik katkılara dönüşmesi, bölge ve ülke ekonomilerinin gelişimini teşvik eden önemli bir etkendir.

Dünyada ve Türkiye'de sayıları hızla artan üniversitelerin ülke ve kent düzeyinde gelişmeye katkı sunduğu görülmektedir. Üniversiteler, ülke ve kent ekonomileri için gelişimin ve değişimin itici gücü olarak kabul edilmektedir. Özellikle İkinci Dünya Savaşı sonrası dönemde iktisadi, teknolojik, bölgesel ve toplumsal gelişmeye duyulan ihtiyaç yükseköğretim kurumlarının sayısındaki artış eğiliminin belirleyicisi olmuştur (Uygun, Mete, Kara ve Bağcl, 2016: 67).

Gelişmekte olan ülkelerin en önemli sorunu iktisadi ve kurumsal gelişmenin nasıl sağlanacağıdır. Uzun dönemli ekonomik gelişmenin başlıca unsuru olan beşeri sermaye bireylerin bilgi ve becerilerinin üretime yansımasını ifade etmektedir. Beşeri sermayenin gelişme sürecindeki önemine ilk olarak değinenler klasik iktisatçılardır. A. Smith 1776 yılında yayınlanan "Ulusların Zenginliği" başlıklı eserinde işbölümü ve uzmanlaşmanın yani beşeri sermayenin üretimi artırmaktaki önemini vurgulamaktadır. Beşeri sermayenin artışı ise eğitim ile yakından ilişkilidir. Dolasıyla beşeri sermayeye yapılan yatırım olarak üniversiteler iktisadi gelişme sürecinde önemli bir role sahiptir (Erdoğan ve Karagöl, 2018: 52). Daha dar bir açıdan bakıldığında üniversiteler, bulundukları kentlerde gerçekleştirdikleri tüketimle beraber istihdamın artması ve yerel ekonominin canlanması bakımından önemli etki yaratmaktadır. Üniversiteler kurulduğu bölgelere nüfus artışı, alt yapı yatırımları, sağlık ve ulaşım hizmetlerinde iyileşme ve işsizliğin azalması gibi katkılar sunmaktadır (Acaroğlu, Kartal ve Güllü, 2017: 2).

Gerek kamu gerekse özel eğitim kurumları, temelde ticari faaliyet içinde olmamalarına karşın yerel ekonomilerin gelişimine önemli ölçüde katkı sunmaktadırlar. Bu kurumların başında ise üniversiteler gelmektedir. Söz konusu katkının farkındaki pek çok Avrupa ülkesi, özellikle 1960 sonrasında geri kalmış bölgelerde yüksek öğretim kurumlarını yaygınlaştırmıştır (Kaşlı ve Serel, 2008: 100). Yakın zamanlarda Türkiye'de de başlayan "her ile bir üniversite" anlayışı sonucunda Türkiye'nin özellikle az geliş̧miş bölgelerine yeni üniversiteler kurulmuştur. Nitekim Yükseköğretim Kurulu verilerine göre Türkiye'de 2003 yılında 76 devlet üniversitesi bulunmaktayken, 2020 yılında bu sayı 129'a yükselmiştir (Yükseköğretim Kurulu, 2021). Kurulan bu üniversitelerin bulundukları bölgelere sunmuş oldukları katkıların boyutunu niceliksel olarak ortaya koyabilmek amacı son zamanlarda önemli bir araştırma alanı olmuştur (Sarkım, Seker, Kurtoğlu ve Kara, 2017: 1200; Beşballı ve Öztürk, 2017; Yayar, Şeker ve Karanfil, 2018; Erdoğan ve Karagöl, 2018; Koç, 2019).

Bu çalışmanın amacı, Bursa Uludağ Üniversitesi'nin (BUÜ) Bursa ekonomisi üzerindeki doğrudan, dolaylı ve uyarılmıs gelir ve istihdam etkilerini ortaya koymaktır. Yazında üniversitede istihdam edilen personel doğrudan istihdam, personele yapılan ödemeler doğrudan gelir etkisi olarak sınıflandırılırken, personel ödemeleri dışındaki üniversite harcamaları ile öğrenci harcamaları dolaylı gelir etkisi, bu harcamalar sonucu ortaya çıkan istihdam ise dolaylı istihdam etkisi olarak sınıflandırılmaktadır. Üniversite kaynakı harcamaların, çarpan etkisi sonucu yaratmış olduğu gelir ve istihdam ise uyarılmış etkiler adı altında sınıflandırılmaktadır (Lewis, 1988: 54-55; Atik, 1999: 100). Yazındaki sınıflandırmaya bağı kalınan bu çalışmada, BUÜ Strateji Geliştirme Daire Başkanlığı'ndan derlenen bilgilerden ve öğrenci harcamalarını hesaplamak için yapılan saha çalışmasından elde edilen verilerden yararlanılmıştır.

Çalışmanın geri kalanı şu şekilde tasarlanmıştır. İkinci bölümde üniversitelerin bulundukları şehirlere ve bölgelere ekonomik katkılarını ortaya koyan yazına yer verilmiştir. Üçüncü bölümde, BUÜ'nün Bursa ekonomisine doğrudan, dolaylı ve uyarılmış etkileri ve bu etkilerin Bursa ekonomisindeki yeri ortaya konulmuştur. Bu bölümde elde edilen bulgular, BUÜ'nün özellikle dolaylı ve uyarılmış etkiler yoluyla yerel ekonomiye önemli bir katkı sunduğunu göstermektedir. Son bölümde ise BUÜ'nün Bursa ekonomisine olan etkisi üzerine genel bir değerlendirme yapılmıştır. 


\section{Yazın Taraması}

Yazında üniversitelerin yerel ekonomilere katkılarını araştıran çok sayıda çalışma bulunmaktadır. Bu çalışmaların bir bölümü ekonomik katkı olarak yalnızca öğrenci harcamaları üzerinde durmuş, bir bölümü ise hem öğrenci harcamalarını hem de üniversitelerin yapmış oldukları harcamaları ekonomik katkı hesaplamalarına dâhil etmişlerdir. Söz konusu çalışmalarda öğrenci harcamalarını belirlemek amacıyla başvurulan başlıca yöntemin anket çalışmaları olduğu, üniversitelerin yapmış oldukları harcamalara ilişkin verilerin ise faaliyet raporlarından elde edildiği görülmektedir.

Kaşlı ve Serel (2008) Balıkesir Üniversitesi Gönen Meslek Yüksekokulu (MYO) öğrencilerinin Gönen ekonomisine olan katkılarını ortaya koymak amacıyla 554 öğrenciye anket uygulamışlardır. Araştırma bulgularına göre 2006-2007 döneminde Gönen MYO' da öğrenimini sürdüren 873 öğrenci Gönen ekonomisine 3.622.950 TL katkı sağlamıştır.

Görkemli (2009; 2011) 2003 yılına ilişkin verilerden yararlanarak Selçuk Üniversitesi'nin Konya ekonomisine katkılarını incelemiştir. Çalışma sonucunda Selçuk Üniversitesi'nin Konya iline 41.069.000 TL doğrudan katkı, 237.554.355 TL dolaylı katkı ve 852.587.466 TL uyarılmış katkı sağladığı belirlenmiştir. Öte yandan Selçuk Üniversitesinin Konya iline 4.205 kişi doğrudan istihdam, 9.497 kişi dolaylı istihdam ve 34.085 kişi uyarılmış istihdam sağladığı hesaplanmıştır.

Selçuk (2012) Atatürk Üniversitesi öğrencilerinin Erzurum ekonomisine katkısını tahmin etmek amacıyla şehir merkezindeki yerleşkede öğrenim gören 400 öğrenciye anket uygulamıştır. Araştırma bulgularına göre öğrencilerin 2012 yılı aylık harcama tutarı 744,66 TL'dir. Bu veriden yola çıkılarak, üniversite yerleşkesinde öğrenim gören 31.276 öğrencinin il ekonomisine bir yılda yaklaşık 186,3 milyon TL katkı sağladığı sonucuna varılmıştır.

Demirelli ve Taşkın (2013) Dumlupınar Üniversitesi öğrencilerinin Kütahya ekonomisine katkısını ortaya koymak amacıyla kent merkezinde öğrenim gören 3.285 öğrenciye anket uygulamışlardır. Araştırma sonucunda 2010 yılında her bir öğrencinin aylık ortalama harcamasının 495 TL olduğu, Dumlupınar Üniversitesinde lisans ve önlisans düzeyinde öğrenim gören 30.450 öğrencinin Kütahya ekonomisine ayda yaklaşık 15 milyon TL katkı sağladığı belirlenmiştir.

Tösten, Çenberlitaş ve Gökoğlan (2013) Dicle Üniversitesi'nde öğrenim gören öğrencilerin Diyarbakır ekonomisine katkısını belirlemek amacıyla 829 lisans ve önlisans öğrencisine anket uygulamışlar ve 20122013 öğretim yılında her bir öğrencinin ayda ortalama 600 TL harcama yaptığı, üniversitede öğrenim gören 27.500 öğrencinin kente olan yıllık katkısının ise 132 milyon TL olduğu sonucuna ulaşmışlardır.

Yayar ve Demir (2013) Gaziosmanpaşa Üniversitesi'ne bağlı yükseköğretim kurumlarının Tokat il ekonomisine katkısını belirlemek amacıyla yapmış oldukları anket çalışmasında, bir öğrencinin 2012 yılı aylık ortalama harcamasının 572,22 TL olduğunu belirlemişler, üniversitede öğrenim gören 20.659 öğrencinin Tokat ekonomisine yıllık katkısını 112.422.346 TL olarak hesaplamışlardır. Çalışmada, üniversite ve üniversite personeli tarafından yapılan harcamaların hesaplamaya dâhil edilmesiyle Tokat ekonomisine yıllık toplam katkının 252.320.356 TL olduğu sonucuna varılmıştır.

Pastor, Perez ve de Guevara (2013) Valensiya bölgesindeki kamu üniversitelerinin bölge ekonomisi üzerindeki etkilerini ölçmek amacıyla yaptıkları çalışmada, Monte Carlo benzetimlerine dayanan bir yöntem kullanarak, bölgedeki üniversiteler, üniversite öğrencileri ve üniversite ziyaretçileri tarafından yapılan harcamaların bölgesel çıktıda yaklaşık 3,05 milyar Avro, bölgesel istihdamda ise yaklaşık 39 bin kişi artışa yol açtığını hesaplamışlardır.

Korkmaz (2015) Bayburt Üniversitesi öğrencilerinin Bayburt ekonomisine olan katkısını, íktisadi ve İdari Bilimler Fakültesi'nde (iiBF) öğrenim gören 300 öğrenciye uygulamış olduğu anket yoluyla incelemiştir. Yapılan araştırmada öğrencilerin aylık ortalama 432,66 TL harcama yaptıkları, 2012-2013 öğretim yılında Bayburt Üniversitesinde öğrenim gören 4.791 öğrencinin Bayburt ekonomisine yılda yaklaşık 16.582.992 TL katkı sunduğu sonucuna varılmışıtır. 
Oxford Economics (2016) tarafından Bath Üniversitesi'nin Bath ve North East Somerset bölgesine ekonomik katkılarını ortaya koymak amacıyla hazırlanan bir rapora göre, Bath Üniversitesi 2014-2015 döneminde bölgede yaklaşık 5.850 kişilik istihdam yaratırken, bölgenin GSYH'sine 294 milyon İngiliz Sterlini değerinde katkı sunmuştur.

Özyakışır ve Şayan (2016) Kafkas Üniversitesi öğrencilerinin Kars ekonomisine katkısını belirlemek üzere yaptıkları çalışmada 425 öğrenciye anket uygulamışlar ve her bir öğrencinin 2015 yılında ayda ortalama 600,19 TL harcama yaptığını belirlemişlerdir. Çalışmada, kayıtlı 16.044 öğrencinin yılın sekiz ayını Kars'ta geçirdikleri varsayılarak kent ekonomisine yılda 77.235.587 TL katkı sağladığı sonucuna ulaşılmıştır.

Gümüş ve Ekiz (2017) Kastamonu Üniversitesi öğrencilerinin tüketim harcamalarının Kastamonu ekonomisine katkısını incelemek amacıyla 667 öğrenciye anket uygulamışlardır. Çalışma sonucunda Kastamonu'daki üniversite öğrencilerinin 2016-2017 akademik yılında şehir ekonomisine ayda yaklaşık 19,5 milyon TL, yılda ise yaklaşık 173 milyon TL katkı sağladığı hesaplanmıştır.

Sarkım vd. (2017) Bozok Üniversitesinde öğrenim gören öğrencilerin tüketim harcamalarının Yozgat ekonomisine etkilerini incelemişlerdir. 2017 yılında yapılan anket çalışmasında öğrencilerin Yozgat'ta bulundukları süre zarfındaki aylık ortalama harcaması 633,47 TL olarak hesaplanmış, bu harcamanın tüm öğrenciler tarafından yapılması durumunda Yozgat ekonomisine bir ayda 7.861.996 TL'lik katkı sağlanacağı sonucuna varılmıştır.

Beşballı ve Öztürk (2017) Artvin Çoruh Üniversitesi'nin Artvin ekonomisine katkısını araştırmak amacıyla 2.200 öğrenciye anket uygulamışlardır. Anket çalışması sonucunda öğrencilerin aylık ortalama harcamaları 640,99 TL olarak hesaplanmıştır. 2016-2017 yılında öğrenim gören 6.398 öğrencinin Artvin ekonomisine toplam katkısının 36.909.832 TL olduğu tespit edilmiştir.

Zhang, Larkin ve Lucey (2017) İrlanda'daki yükseköğretim kurumlarının ekonomik etkilerini girdi-çıktı yöntemi kullanarak araştırdıkları çalışmalarında, 2010-2011 döneminde 2,6 milyar Avro brüt geliri olan söz konusu kurumların ülke çapında 10,6 milyar Avro brüt çıktı yaratmış oldukları sonucuna varmışlardır.

Yayar vd. (2018) Amasya Üniversitesi'nin il ekonomisine olan etkisini belirlemek amacıyla 2016 yılında Amasya'da öğrenimini sürdüren 716 öğrenciye anket uygulamışlar ve her bir öğrencinin aylık ortalama tüketim harcamasının 697,15 TL, kayıtlı 11.580 öğrencinin bir öğretim yılındaki harcama tutarının ise 72.656.973 TL olduğunu tespit etmişlerdir. Çalışmada, öğrenci harcamalarına Amasya Üniversitesi'nin 2016 yılı bütçe harcamaları eklenerek üniversitenin Amasya ekonomisine bir yıldaki toplam etkisinin 157.652.627 TL olduğu sonucuna varılmıştır.

Erdoğan ve Karagöl (2018) 2016-2017 öğretim yılında Bingöl Üniversitesi'nde okuyan öğrencilerin Bingöl ekonomisine olan katkıını incelemek amacıyla 850 öğrenciye anket uygulamışlardır. Anket çalışmasında öğrencilerin Bingöl'de yılda ortalama 9 ay bulundukları, bu zaman diliminde ayda ortalama 670 TL harcama yaptıkları belirlenmiştir. 2016-2017 öğretim yılında Bingöl üniversitesinde öğrenim gören öğrenci sayısı 14.545 olduğu için Bingöl ekonomisine toplam katkının yaklaşık 88 milyon TL olduğu sonunca varılmıştır. Buna ilaveten, 2017 yılında Bingöl Üniversitesi'nde çalışan 815 personele yapılan 9 aylık maaş ödemesi yoluyla Bingöl ekonomisine sağlanan katkı 30 milyon TL'ye yakındır.

Saray ve Çeker (2018) İnönü Üniversitesi'nin Malatya ekonomisine katkısını belirlemek üzere yaptıkları çalışmada, üniversitenin 2015-2016 akademik yılında bütçe, döner sermaye ve öğrenci harcamaları yoluyla Malatya gayrisafi yerel hâsılasına 171.100.045 TL doğrudan, 314.706.307 TL dolaylı ve 288.812.258 TL uyarılmıs katkı sağladığını belirlemişlerdir. Öte yandan çalışmada İnönü Üniversitesi'nin yerel istihdama katkısının 13.525 kişi olduğu hesaplanmıştır.

Glücker, Panitz ve Wütke (2018) Almanya'nın Baden-Württemberg bölgesindeki dokuz devlet üniversitesinin bölge ekonomisine etkisini araştırdıkları çalışmalarında, söz konusu üniversitelerin 2012 yılında mal ve hizmet alımları, personel, yatırım ve öğrenci harcamaları yoluyla bölgede yaklaşık 3,7 milyar Avro katma değer, 63 bin civarında istihdam yarattıkları sonucuna ulaşmışlardır. 
Kotosz, Guanard-Anderson ve Lukovics (2018) üniversitelerin yerel ekonomiye etkilerini uluslararası karşılaştırmalı bir yaklaşımla ele almışlardır ve bu amaçla, Fransa'daki Lorraine Üniversitesi'nin Metz kentine ekonomik etkisini, Macaristan'daki Szeged Üniversitesi'nin Szeged kentine ekonomik etkisiyle karşılaştırmışlardır. 2014 yılı verilerinin kullanıldığı çalışmada Lorraine Üniversitesi'nin Metz kenti GSYH'sine katkısının \%0,02, Szeged Üniversitesi'nin Szeged kenti GSYH'sine katkısının ise \%4 olduğu belirlenmiştir.

Kalkan, Dilek ve Kesgingöz (2019) Kastamonu Üniversitesi'nin şehir ekonomisine yaptığı katkıyı incelemek amacıyla 430 öğrenciye anket uygulamışlardır. Anket çalışması sonucunda öğrencilerin 2018 yılı aylık otalama harcamaları 895,68 TL olarak hesaplanmıştır. Söz konusu çalışmada Kastamonu Üniversitesi'nin bütçe, döner sermaye ve öğrenci harcamaları yoluyla 2018 yılında Kastamonu gayrisafi hâsılasına toplam 4.822.012.314 TL doğrudan, dolaylı ve uyarıımış katkı sağladığı, bu katkının Kastamonu gayrisafi hâsılasına oranının ise $\% 39,3$ olduğu hesaplanmıştır.

Koç (2019) Hitit Üniversitesi öğrenci harcamalarının Çorum ekonomisine katkısını ölçmek amacıyla iiBF'de öğrenim gören 637 öğrenciye anket uygulamış ve bir öğrencinin 2016-2017 eğitim dönemindeki aylık ortalama harcamasının 630 TL olduğunu belirlemiştir. Çalışmada, Hitit Üniversitesi'nin 2016-2017 eğitim döneminde öğrenci harcamaları yoluyla Çorum ekonomisine yıllık 105 milyon TL katkı sunduğu hesaplanmıştır.

Valero ve Van Reenen (2019) tarafından, yaklaşık 15.000 üniversitenin bulunduğu 78 ülkedeki 1.500 bölge üzerine UNESCO kaynak materyalleri kullanılarak yapılan çalışmada, bir bölgedeki üniversite sayısındaki \%10 artışın kişi başına düşen GSYH'da \%0,4 artışla pozitif ilişkili olduğu tespit edilmiştir.

Çoban ve Çoban (2020) Amasya Üniversitesi Suluova Meslek Yüksek Okulu öğrencilerinin Suluova ilçesine ekonomik katkısını incelemek amacıyla 124 öğrenciye anket uygulamışlardır. Öğrencilerin aylık ortalama harcama tutarının 484,23 TL olarak tespit edildiği çalışmada, öğrenci harcamalarının 2017-2018 akademik döneminde ilçe ekonomisine 3.800.327 TL katkı sağladığı sonucuna varılmıştır.

Atılgan Yaşa ve Bakırtaş (2020) Manisa Celal Bayar Üniversitesi Salihli iiBF ve Salihli MYO öğrencilerinin Salihli ekonomisine katkısını araştırdıkları çalışmalarında 750 öğrenciye anket uygulamışlardır. Bir öğrencinin aylık ortalama harcamasının 1.479,19 TL olarak belirlendiği çalışmada, söz konusu iki eğitim kurumunun 2019-2020 eğitim-öğretim döneminde bütçe ve öğrenci harcamaları yoluyla Salihli ekonomisine 26.329.875 TL katkı sağladığı, bu katkıya bağlı kısa ve uzun dönemli uyarılmış gelir etkilerinin ise sırasıyla 60.400.527 TL ve 87.757.173 TL olduğu tespit edilmiştir.

\section{Bursa Uludağ Üniversitesi'nin Bursa Ekonomisine Etkileri}

BUÜ 11 Nisan 1975 yılında kurulmuştur. Mevcut durumda üniversiteye bağlı olan 15 fakülte, 2 yüksekokul, 16 meslek yüksekokulu, 1 konservatuar, 4 enstitü, 25 uygulama ve araştırma merkezi ile 1 araştırma merkezi ve rektörlüğe bağlı olarak kurulan 5 bölüm bulunmaktadır (Bursa Uludağ Üniversitesi, 2019: 20). 2017-2018 eğitim-öğretim yılında BUÜ’de toplam 74.822 öğrenci öğrenim görmüştür (Bkz. Tablo 1). Yükseköğretim Kurulu verilerine göre BUÜ, 2017-2018 öğretim yılında yüz yüze öğrenim gören öğrenci sayısı bakımından Türkiye'deki üniversiteler arasında yedinci sırada yer almıştır (Yükseköğretim Kurulu, 2021).

Hesaplamalarda kullanılacak olan üniversite kaynaklı harcamalardan, kent merkezindeki veya ilçelerdeki birimler tarafından ne kadar harcama yapıldığını ayrıştırmak ve bu harcamaların ekonomik faaliyetlere ne kadar etki yaptığını ayrı ayrı hesaplamak mümkün olmamıştır. Bu sebeple harcamalar bütününden ayrılmadan incelenmiştir. Bursa iline bağlı ilçelerde bulunan yüksekokulların ve fakültelerin Bursa bölgesinde etki yaratması beklendiğinden üniversiteye bağı tüm birimlerin harcamalarının Bursa geneline etkide bulunduğu varsayımı ile hareket edilmiştir. Üniversite kaynaklı harcamalar hesaplanırken 2018 yılına ait verilerden yararlanılmıştır. Dolayısıyla BUÜ’nün Bursa kent ekonomisine olan etkileri 2018 yılı esas alınarak hesaplanmıştır. BUÜ'nün Bursa ekonomisine olan etkileri yazındaki sınıflandırmaya uygun olarak doğrudan, dolaylı ve uyarılmış etkiler başlıkları altında incelenecektir. 
Tablo 1. 2017-2018 Eğitim-Öğretim Yılında BUÜ Öğrencilerinin Mekânsal Dağılımı

\begin{tabular}{|l|l|c|c|}
\hline \multicolumn{2}{|l|}{ Birimler } & Öğrenci Sayısı & Yüzde (\%) \\
\hline \multirow{3}{*}{$\begin{array}{l}\text { Bursa Kent } \\
\text { Merkezindeki } \\
\text { Birimler }\end{array}$} & Görükle Yerleşkesi & 54.539 & $\mathbf{7 2 , 9}$ \\
\cline { 2 - 4 } & Ali Osman Sönmez Yerleşkesi & 3.871 & 5,2 \\
\cline { 2 - 4 } & Illahiyat Fakültesi (Fethiye) & 2.906 & 3,8 \\
\cline { 2 - 4 } & Bursa Merkez & $\mathbf{6 1 . 3 1 6}$ & $\mathbf{8 1 , 9}$ \\
\hline \multirow{4}{*}{$\begin{array}{l}\text { Bursa } \\
\text { İlçelerindeki } \\
\text { Birimler }\end{array}$} & İlçelerdeki MYO'lar & 11.571 & 15,5 \\
\cline { 2 - 4 } & İnegöl İşletme Fakültesi & 711 & 0,9 \\
\cline { 2 - 4 } & Güzel Sanatlar Fakültesi (Mudanya) & 214 & 0,3 \\
\cline { 2 - 4 } & Hukuk Fakültesi (Gemlik) & 1.010 & 1,4 \\
\cline { 2 - 4 } & İlçeler Toplam & $\mathbf{1 3 . 5 0 6}$ & $\mathbf{1 8 , 1}$ \\
\hline Genel Toplam & & $\mathbf{7 4 . 8 2 2}$ & $\mathbf{1 0 0 , 0 0}$ \\
\hline
\end{tabular}

Kaynak: Bursa Uludağ Üniversitesi (2019: 48).

\subsection{Doğrudan Etkiler}

Üniversiteler, hem yaptığı bütçe ve döner sermaye harcamaları hem de kendi bünyesinde ve bağı kurumlar aracılığıyla istihdam ettiği personel sayesinde kent ekonomisine önemli katkılarda bulunmaktadır. Kent ekonomisi üzerindeki bu etkiler doğrudan gelir ve doğrudan istihdam olmak üzere ikiye ayrılmaktadır.

Üniversitenin yarattığı istihdam ve gelir doğrudan kent ekonomisi ile ilgilidir. Üniversite bünyesinde belli bir zaman diliminde istihdam edilen personel doğrudan istihdam etkisini oluşturmaktadır. Üniversite bünyesinde istihdam edilen personele ödenen ücretler sonucu ortaya çıkan ekonomik etki ise doğrudan gelir etkisi olarak adlandırılmaktadır (Atik, 1999: 100). Üniversitelerde çalışan personel genellikle üniversitelerin bulunduğu kentlerde ikamet ettiği için kişisel harcamaları kent ekonomisine doğrudan gelir olarak yansımakta, bu harcamalar yerel ekonomide genişletici etki yaratmaktadır.

BUÜ'de yıllara ve konumlarına göre istihdam edilen personel sayıları Tablo 2'de görülmektedir. 2018 yılında BUÜ, 6.619 kişilik doğrudan istihdam yaratmıştır.

Tablo 2. BUÜ’nün Yıllara Göre Personel Sayıları

\begin{tabular}{|l|c|c|c|}
\hline & $\mathbf{2 0 1 6}$ & $\mathbf{2 0 1 7}$ & $\mathbf{2 0 1 8}$ \\
\hline Akademik Personel & 2.421 & 2.348 & 2.435 \\
\hline Yabancı Uyruklu Akademik Personel & 24 & 18 & 17 \\
\hline İdari Personel & 2.175 & 2.133 & 2.067 \\
\hline Sözleşmeli İdari Personel (4/b) & 125 & 177 & 322 \\
\hline İşçi & 4 & 2 & 2 \\
\hline Geçici Personel (4/c) & 17 & 17 & - \\
\hline Sürekli İşçi (4/D) & - & - & 1.776 \\
\hline Toplam & $\mathbf{4 . 7 6 6}$ & $\mathbf{4 . 6 9 5}$ & $\mathbf{6 . 6 1 9}$ \\
\hline
\end{tabular}

Kaynak: Bursa Uludağ Üniversitesi (2019: 42)

BUÜ'de istihdam edilen personele yapılan ödemeler (maaş, ek ders, döner sermaye, vb.), diğer bir ifadeyle, BUÜ’nün Bursa ekonomisi üzerindeki doğrudan gelir etkisi Tablo 3'te görülmektedir.

Tablo 3. BUÜ’nün 2018 Yılı Doğrudan Gelir Etkisi

\begin{tabular}{|l|c|c|}
\hline \multirow{2}{*}{ Harcama Kalemleri } & \multicolumn{2}{|c|}{ Harcama Tutarı(TL) } \\
\cline { 2 - 3 } & Brüt & Net \\
\hline Üniversite Bütçesinden & 333.324 .131 & 249.993 .098 \\
\hline Döner Sermaye İşletmesinden & 112.820 .966 & 84.615 .725 \\
\hline Toplam & $\mathbf{4 4 6 . 1 4 5 . 0 9 7}$ & $\mathbf{3 3 4 . 6 0 8 . 8 2 3}$ \\
\hline
\end{tabular}

Kaynak: Bursa Uludağ Üniversitesi (2019: 70-91). 
Tablo 3'te personele yapılan ödemeler iki satırda gösterilmektedir. Üniversite bütçesinden başlıklı ilk satırda BUÜ'nün personele yaptığı maaş ve ücret ödemeleri yer almaktadır. Tablodaki brüt tutar sosyal güvenlik prim kesintilerini içermemesine karşın gelir vergisi kesintisi nedeniyle personelin eline geçen tutarı vermemektedir. Gelir vergisi kesintisi sonrasında personelin eline geçen net tutar, brüt miktarın yaklaşık \%75'dir. İkinci satırda ise döner sermaye personel giderleri görülmektedir. Döner sermayeden personele yapılan net ödeme ise brüt değerden gelir ve damga vergisi çıkarılarak hesaplanmıştır. Buna göre 2018 yılında üniversite personelinin eline geçen toplam net gelir 334.608.823 TL'dir.

\subsection{Dolaylı Etkiler}

Dolaylı etkiler, üniversiteler tarafından emek dışındaki faktör sahiplerine yapılan ödemeler ile öğrenci harcamaları sonucunda ortaya çıkan gelir ve istihdam artışını ifade etmektedir (Lewis, 1988: 54; Atik, 1999: 100). Öğrencilerin, üniversitelerin ve üniversitelere bağlı kuruluşların mal ve hizmet alımları kent ekonomileri için önemli bir gelir ve istihdam kaynă̆ıdır.

BUÜ'nün Bursa ekonomisi üzerindeki dolaylı gelir etkisi, bütçe ve döner sermaye harcamalarının Bursa ekonomisinde kalan kısmı ile öğrenci harcamaları toplanarak hesaplanabilir (Lewis, 1988: 54-55; Atik, 1999: 104-107). Dolaylı istihdamı hesaplayabilmek içinse dolaylı gelirin yanı sıra kişi başına hizmet üretim (KBHÜ) değerinin bilinmesi gerekmektedir. Bir ülkenin veya bölgenin belirli bir dönemdeki toplam hizmet üretim değeri, aynı dönemde hizmet sektöründe çalışanların sayısına bölünerek KBHÜ değeri elde edilebilir. Üniversite tarafından kentte yaratılan dolaylı gelir, KBHÜ değerine bölündüğünde dolaylı istihdam sayısı bulunmaktadır (Atik, 1999: 104). İzleyen alt bölümlerde öncelikle BUÜ’nün dolaylı gelir etkisi, ardından dolayı gelir kaynaklı dolaylı istihdam etkisi ortaya konulacaktır.

\subsubsection{Dolaylı Gelir}

\section{Bütçe Harcamaları}

BUÜ’nün 2018 yılı personel giderleri dışındaki bütçe harcamalarının toplamı Tablo 4'te görüldüğü üzere 222.501.807 TL'dir. Bu harcamanın Bursa ekonomisine katkısının hesaplanabilmesi için Bursa ekonomisinde kalan tutarın belirlenmesi gerekmektedir. Bu amaçla öncelikle sosyal güvenlik kurumlarına aktarılan prim giderleri harcama toplamından çıkarılmış ve kalan tutar 167.739.327 TL olarak hesaplanmıştır.

Tablo 4. BUÜ’nün 2018 Yılı Personel Giderleri Dışındaki Bütçe Harcamaları

\begin{tabular}{|l|c|}
\hline Harcama Kalemleri & Harcama Tutarı (TL) \\
\hline Sosyal Güvenlik Prim Giderleri & 54.762 .480 \\
\hline Mal ve Hizmet Alım Giderleri & 61.253 .624 \\
\hline Cari Transferler & 17.627 .056 \\
\hline Sermaye Giderleri & 88.858 .647 \\
\hline Toplam & $\mathbf{2 2 2 . 5 0 1 . 8 0 7}$ \\
\hline
\end{tabular}

Kaynak: Bursa Uludağ Üniversitesi (2019: 70).

BUÜ İdari ve Mali İşler Daire Başkanlığı yetkilileri tarafından verilen bilgilere göre mal ve hizmet alımları, cari transferler ve sermaye giderlerinden oluşan 167.739 .327 TL harcamanın yaklaşık \%60'lık bölümü Bursa ekonomisinde kalmaktadır. Buna göre BUÜ’nün 2018 yılı bütçe harcamalarından kent ekonomisine aktardığı dolaylı gelir 100.643.596 TL'dir.

\section{Döner Sermaye Harcamaları}

Ağırlıklı olarak BUÜ Tıp Fakülte Hastanesi bünyesinde faaliyet gösteren döner sermaye işletmesi aracılığıyla da kent ekonomisine kaynak aktarılmaktadır. Döner sermaye işletmesinin doğrudan gelir etkisi yukarıda incelenmiştir. Bu kısımda ise döner sermaye işletmesinin kent ekonomisine dolaylı gelir etkisi incelenmektedir. 
Üniversitelerin Yerel Ekonomiye Etkileri: Bursa Uludağ Üniversitesi Örneği

Tablo 5. BUÜ Döner Sermaye İşletmesinin 2018 Yılı Personel Giderleri Dışındaki Harcamaları

\begin{tabular}{|l|c|}
\hline Harcama Kalemleri & Harcama Tutarı (TL) \\
\hline Hizmet Alımı & 97.082 .897 \\
\hline Diğer Cari & 131.179 .140 \\
\hline Yatırım Giderleri & 2.987 .140 \\
\hline Transfer Giderleri & 24.876 .498 \\
\hline Toplam & $\mathbf{2 5 6 . 1 2 5 . 6 7 5}$ \\
\hline
\end{tabular}

Kaynak: Bursa Uludağ Üniversitesi (2019: 91).

BUÜ döner sermaye işletmesinin 2018 yılı personel giderleri dışındaki harcamaları Tablo 5'te görülmektedir. Öte yandan döner sermaye harcamalarından transfer giderlerinin de (hazineye aktarılan pay, karşılıksız ödemeler) düşülmesi gerekmektedir. Geriye kalan hizmet alımı, diğer cari giderler ve yatırım giderlerinin tutarı 231.249.177 TL'dir. Döner Sermaye Işletmesi Saymanlığı'ndan edinilen bilgiye göre söz konusu harcamalarının yaklaşık \%65'i Bursa ekonomisinde kalmaktadır. Buna göre BUÜ Döner Sermaye İşletmesi 2018 yılında yapmış olduğu harcamalarla Bursa ekonomisinde 150.311.965 TL dolaylı gelir etkisi yaratmıştır.

\section{Öğrenci Harcamaları}

Üniversitelerin yerel ekonomiler üzerindeki dolaylı gelir etkilerinin hesaplanmasında dikkate alınması gereken önemli bir kalem öğrenci harcamalarıdır. Öğrenci harcamalarını ölçmek üzere BUÜ'de kayıtlı öğrencilerin \%70'ini oluşturan, kent merkezinde öğrenim gören 52.327 lisans ve önlisans öğrencisi temel alınarak 3 Nisan 2018 ile 4 Mayıs 2018 tarihleri arasında yüz yüze anket çalışması yapılmıştır. Öğrenim süreleri boyunca genellikle Bursa dışında yaşayan lisansüstü öğrenciler anket kapsamına alınmamıştır. Ana kütleyi oluşturan öğrenci sayısı yaklaşık 50.000 birim olduğundan \pm 5 hata payı ile $\% 95$ güvenirlik aralığı düzeyinde çekilecek örneklem sayısı 381 olarak belirlenmiştir (Bayram, 2017: 25). Belirlenen örneklem hacmi kota örnekleme yöntemine uygun olarak öğrenim birimi ve cinsiyete göre dağıtılmıştır (Bkz. Tablo 6). Elde edilen verilerinin analizi için SPSS paket programı kullanılmıştır.

Tablo 6. Ankete Katılan Öğrencilerin Öğrenim Birimi ve Cinsiyete Göre Dağılımı

\begin{tabular}{|l|c|c|c|}
\hline & Kız & Erkek & Toplam \\
\hline Tıp Fakültesi & 8 & 8 & 16 \\
\hline İktisadi ve İdari Bilimler Fakültesi & 47 & 53 & 100 \\
\hline Mühendislik Fakültesi & 12 & 33 & 45 \\
\hline Veteriner Fakültesi & 3 & 4 & 7 \\
\hline Ziraat Fakültesi & 7 & 8 & 15 \\
\hline Eğitim Fakültesi & 27 & 13 & 40 \\
\hline İlahiyat Fakültesi & 15 & 8 & 23 \\
\hline Fen-Edebiyat Fakültesi & 29 & 16 & 45 \\
\hline Mimarlık Fakültesi & 3 & 2 & 5 \\
\hline Spor Bilimleri Fakültesi & 2 & 3 & 5 \\
\hline Sağlık Bilimleri Fakültesi & 3 & 2 & 5 \\
\hline Devlet Konservatuarı & 1 & 0 & 1 \\
\hline Sağlık Hizmetleri Meslek Yüksekokulu & 4 & 2 & 6 \\
\hline Teknik Bilimler Meslek Yüksekokulu & 11 & 33 & 44 \\
\hline Sosyal Bilimler Meslek Yüksekokulu & 14 & 10 & 24 \\
\hline Toplam & $\mathbf{1 8 6}$ & $\mathbf{1 9 5}$ & $\mathbf{3 8 1}$ \\
\hline
\end{tabular}


Yapılan anket çalışmasının sonucunda 2017-2018 öğretim yılında öğrencilerin ortalama aylık harcamalarının 937,99 TL olduğu hesaplanmıştır. Bu tutar, 2017-2018 öğretim yılında BUÜ'nün tüm yerleşkelerinde öğrenim gören lisans ve önlisans öğrenci sayısıyla (65.833) çarpılarak Bursa ekonomisine aylık olarak aktarılan dolaylı gelirin 61.750.695,7 TL olduğu hesaplanmıştır.

Öğrenci harcamaları yoluyla yıl boyunca kent ekonomisine aktarılan dolaylı gelirin hesaplanabilmesi için öğrencilerin Bursa'da geçirdikleri sürenin belirlenmesi gerekmektedir. Yapılan saha araştırması sonuçları ortalama hesabına göre değerlendirildiğinde, Bursa'da yaşayan 163 öğrencinin yılın 11,56 ayını, Bursa dışından gelen 218 öğrencinin ise yılın 9,12 ayını Bursa'da geçirdiği görülmektedir (Bkz. Tablo 7). ${ }^{1}$ Bu sürelerin ankete katılan öğrenci sayısına göre ağırlıklı ortalaması 10,16 aydır.

Tablo 7. Ankete Katılan Öğrencilerin Bursa'da Bulunma Süreleri

\begin{tabular}{|l|c|c|}
\hline & Öğrenci Sayısı & Bursa'da Kalınan Ortalama Süre (Ay) \\
\hline Bursa'da Yaşayanlar & 163 & 11,56 \\
\hline Bursa Dışından Gelenler & 218 & 9,12 \\
\hline
\end{tabular}

Öğrencilerin aylık harcama tutarı olan 61.750.695,7 TL ile Bursa'da geçirdikleri ağrılıklı ortalama süre olan 10,16 ay çarpıldığında, BUÜ’nün 2018 yılında öğrenci harcamaları yoluyla kent ekonomisine yaklaşık 627.387.068 TL katkı sağladığı ortaya çıkmaktadır.

\section{Dolaylı Gelir Etkisi}

Bütçe, döner sermaye ve öğrenci harcamaları yoluyla sağlanan dolaylı gelir katkılarının toplanmasıyla BUÜ’nün Bursa ekonomisi üzerindeki 2018 yılı dolaylı gelir etkisinin 878.342.629 TL olduğu hesaplanmıştır (Bkz. Tablo 8).

Tablo 8. BUÜ'nün 2018 Yılı Dolaylı Gelir Etkisi

\begin{tabular}{|l|c|}
\hline Harcama Kalemleri & Dolaylı Gelir (TL) \\
\hline Bütçe Harcamaları & 100.643 .596 \\
\hline Döner Sermaye Harcamaları & 150.311 .965 \\
\hline Öğrenci Harcamaları & 627.387 .068 \\
\hline Toplam & $\mathbf{8 7 8 . 3 4 2 . 6 2 9}$ \\
\hline
\end{tabular}

Kaynak: Yazarlar tarafından hazırlanmıştır.

\subsubsection{Dolaylı İstihdam}

BUÜ’nün dolaylı istihdam etkisini hesaplayabilmek için öncelikle Bursa ili KBHÜ değerini belirlemek gerekmektedir. TÜiK (2020) veri tabanında Bursa GSYH'sinin sektörlere göre dağılımı bulunmasına karşın Bursa'da hizmet sektöründe istihdam edilenlerin sayısı bulunmamaktadır. Bu nedenle İstatistiki Bölge Birimleri Sınıflamasına göre Bursa'nın dâhil olduğu TR41 Bölgesi GSYH ve istihdam verileri kullanılmıştır. TR41 Bölgesinde 2018 yılında hizmet sektörünün GSYH'ye olan katkısı 87.705.996 TL, hizmet sektöründe istihdam edilen çalışan sayısı ise 724 bindir. Bu verilere göre TR41 Bölgesinde 2018 yılı KBHÜ değeri (87.705.996 TL/724.000) 121.141 TL'dir. BUÜ tarafından yaratılan dolaylı gelir, Bursa için de geçerli olduğu varsayılan TR41 Bölgesi 2018 yılı KBHÜ değerine bölündüğünde BUÜ'nün dolaylı istihdam katkısı elde edilmektedir. Tablo 9'da görüldüğü üzere BUÜ'nün dolaylı istihdam katkısı 7.251 kişidir. 
Tablo 9. BUÜ’nün 2018 Yılında Bursa Ekonomisine Dolaylı İstihdam Etkisi

\begin{tabular}{|l|c|c|c|}
\hline Harcama Kalemleri & Dolaylı Gelir (TL) & $\begin{array}{c}\text { TR41 Bölgesi } \\
\text { KBHÜ (2018) }\end{array}$ & $\begin{array}{c}\text { Dolaylı İstihdam } \\
\text { (Kişi) }\end{array}$ \\
\hline Bütçe Harcamaları & 100.643 .596 & & 831 \\
\hline Döner Sermaye Harcamaları & 150.311 .965 & \multirow{2}{*}{121.141} & 1.241 \\
\cline { 1 - 2 } \cline { 1 - 1 } Öğrenci Harcamaları & 627.387 .068 & & $\mathbf{7 . 2 5 1}$ \\
\hline
\end{tabular}

Kaynak: Yazarlar tarafından hazırlanmıştır

\subsection{BUÜ Kaynaklı Harcamaların Bursa Ekonomisindeki Yeri}

TÜiK tarafından hazırlanan III Bazında Gayrisafi Yurtiçi Hasıla verilerinden yararlanılarak, BUÜ kaynaklı harcamaların Bursa hizmet sektörü ve Bursa GSYH'si içindeki payı hesaplanabilir. Bunun için öncelikle BUÜ'nün doğrudan ve dolaylı gelir etkilerinin toplanması gerekmektedir. Tablo 10 'da görüldüğü üzere BUÜ'nün 2018 yılı doğrudan ve dolaylı gelir etkilerinin toplamı 1.212.951.452 TL olarak hesaplanmıştır.

Tablo 10. BUÜ’nün 2018 Yılı Toplam Gelir Etkisi

\begin{tabular}{|l|c|}
\hline Harcama Kalemleri & Tutar (TL) \\
\hline Doğrudan Gelir & 334.608 .823 \\
\hline Dolaylı Gelir & $\mathbf{8 7 8 . 3 4 2 . 6 2 9}$ \\
\hline Toplam Gelir Etkisi & $\mathbf{1 . 2 1 2 . 9 5 1 . 4 5 2}$ \\
\hline
\end{tabular}

Kaynak: Yazarlar tarafından hazırlanmıştır.

TÜik (2020) verilerine göre 2018 yılında hizmet sektörünün Bursa GSYH'sine sunduğu katkı 64.909.827.000 TL ve Bursa ili GYSH değeri ise 155.316.701.000 TL'dir. Buna göre BUÜ’nün 2018 yılında Bursa hizmet sektörü içindeki payı yaklaşık olarak \%1,87 iken Bursa GSYH'sindeki payı ise \% 0,78'e eşittir.

\subsection{Uyarılmış Etkiler}

Uyarılmış etkiler, yerel ekonomide doğrudan ve dolaylı gelir yaratılması sonucu, bu gelirin alıcılar tarafından kent ekonomisinde üretilen mal ve hizmetlere harcanması yoluyla ortaya çıkmaktadır. Bu uyarılmış etki "Keynesyen çarpan" olarak bilinmektedir. Keynesyen harcama çarpanının temelinde, bir kişinin harcamalarındaki artışın (azalışın) toplam gelirde kendisinin birkaç katı kadar artışa (azalışa) neden olduğu varsayımı bulunmaktadır (Lewis, 1988: 55). Buna göre üniversitelerin kendisi, personeli ve öğrencileri tarafından yapılan harcamalar yerel ekonomide çarpan etkisine bağlı olarak birkaç kat gelir artışına neden olmaktadır.

Bursa ekonomisinde BUÜ kaynaklı harcamalar sonucunda ortaya çıkan uyarılmış etkiyi hesaplayabilmek için harcama çarpanı katsayına ihtiyaç duyulmaktadır. Çarpan katsayını hesaplayabilmek için gerekli olan marjinal tüketim eğilimi basit Keynesyen tüketim fonksiyonundan elde edilebilir. Basit Keynesyen tüketim fonksiyonunu tahmin etmek üzere (1) numaralı denklemde gösterilen basit regresyon modeli oluşturulmuştur.

$$
C_{t}=b_{0}+b_{1} Y_{t}+\varepsilon_{t}
$$

Modelde, $C_{t} t$ dönemi özel nihai tüketim harcamalarını, $b_{0}$ otonom tüketim harcamalarını, $b_{1}$ marjinal tüketim eğilimini, $Y_{t} t$ dönemi GSYH değerini ve $\varepsilon_{t}$ hata terimini simgelemektedir. En küçük kareler yöntemiyle E-views paket programı kullanılarak tahmin edilen modelde, TÜiK (2020) tarafından yayınlanan 2008:12019:4 dönemi zincirlenmiş hacim cinsinden özel tüketim harcamaları ile zincirlenmiş hacim cinsinden harcamalar yöntemiyle gayrisafi yurtiçi hâsıla verileri kullanılmıştır. Çarpan katsayısının hesaplanmasına ilişkin ayrıntılar ek olarak verilmiştir. 
Yapılan tahmin sonucunda marjinal tüketim eğilimi 0,529, çarpan katsayısı ise 2,12 olarak bulunmuştur. Türkiye ekonomisine ilişkin verilerle tahmin edilen çarpan katsayının Bursa ekonomisi için de geçerli olduğu varsayılmıştır. Tablo 11'de görüldüğü üzere BUÜ'nün 2018 yılındaki faaliyetleri sonucu ortaya çıkan uyarılmış gelir etkisi 2.571.457.078 TL'dir. Elde edilen bu değer, Bursa ili 2018 yılı GSYH'sine oranlandığında BUÜ kaynaklı harcamaların uyarılmış gelir etkisinin Bursa GSYH'si içindeki payının yaklaşık olarak \%1,65 olduğu ortaya çıkmaktadır. Diğer yandan, uyarılmış gelir etkisi TR41 Bölgesi 2018 yılı KBHÜ değerine bölünerek BUÜ’nün uyarılmış istihdam etkisinin 21.227 kişi olduğu hesaplanmıştır. (Bkz. Tablo 12).

Tablo 11. BUÜ’nün 2018 Yılı Uyarılmış Gelir ve İstihdam Etkileri

\begin{tabular}{|l|c|c|c|c|}
\hline & Tutar (TL) & \multirow{2}{*}{$\begin{array}{c}\text { Çarpan } \\
\text { Katsayısı }\end{array}$} & $\begin{array}{c}\text { Uyarılmış Gelir } \\
\text { (TL) }\end{array}$ & $\begin{array}{c}\text { Uyarılmış } \\
\text { istihdam (Kişi) }\end{array}$ \\
\hline Dolaylı Gelir & 878.342 .629 & \multirow{3}{*}{2,12} & 1.862 .086 .373 & 15.371 \\
\cline { 1 - 2 } \cline { 5 - 5 } Doğrudan Gelir & 334.608 .823 & & 709.370 .705 & 5.856 \\
\cline { 1 - 2 } \cline { 5 - 6 } Toplam & $\mathbf{1 . 2 1 2 . 9 5 1 . 4 5 2}$ & & $\mathbf{2 . 5 7 1 . 4 5 7 . 0 7 8}$ & $\mathbf{2 1 . 2 2 7}$ \\
\hline
\end{tabular}

Kaynak: Yazarlar tarafından hazırlanmıştır.

\section{Sonuç}

Bilgi temelli ekonomilerin başlıca unsurlarından biri olan üniversiteler bilgi üretiminin ve bu bilgiyi kullanacak olan bireylerin yetiştirildiği merkezlerdir. Üniversiteler araştırma kurumları olarak ülkelerin toplumsal ve ekonomik gelişimi üzerinde uzun dönemli etkiler yaratırken, eğitim kurumları olarak bireylerin gelişimine katkı sunmaktadırlar. Öte yandan üniversitelerin uzun dönemli etkileri dışında bulundukları bölge ekonomisi üzerinde kısa dönemli etkileri söz konusudur. Üniversitelerin bulundukları kente kısa dönem ekonomik katkıları gelir ve istihdamdaki artıştır. Bu çalışmada Bursa Uludağ Üniversitesi'nin Bursa ekonomisi üzerindeki doğrudan, dolaylı ve uyarılmış gelir ve istihdam etkilerinin belirlenmesi amaçlanmıştır.

Bursa Uludağ Üniversitesi 2017-2018 eğitim-öğretim yılında 6.619 kişiye doğrudan istihdam sağlarken, istihdam edilen personele ödemiş olduğu ücret ve maaşlar ile 2018 yılında Bursa ekonomisinde 334.608.823 TL doğrudan gelir etkisi yaratmıştır. Bursa Uludağ Üniversitesi'nin personel ödemeleri dışındaki bütçe ve döner sermaye harcamaları ile öğrenci harcamalarının kent ekonomisi üzerindeki dolaylı gelir etkisi 878.342.629 TL olup, bu gelir etkisine bağlı olarak ortaya çıkan dolaylı istihdam ise 7.251 kişidir. Bursa Uludağ Üniversitesi'nin doğrudan ve dolaylı gelir etkilerinin toplamına bağlı olarak ortaya çıkan uyarılmış gelir etkisinin 2.571.457.078 TL, uyarılmış istihdam etkisinin ise 21.227 kişi olduğu sonucuna ulaşılmıştır. Bursa GSYH'sine doğrudan ve dolaylı gelir etkileriyle $\% 0,78$, uyarılmış gelir etkisiyle $\% 1,65$ düzeyinde katkı sağladığı dikkate alındığında Bursa Uludağ Üniversitesi'nin yerel ekonomi açısından önemli bir kurum olduğu anlaşılmaktadır.

\section{Beyan ve Açıklamalar (Declarations and Disclosures)}

Yazarların Etik Sorumlulukları (Ethical Responsibilities of Authors): Bu çalışmanın yazarları, araştırma ve yayın etiği ilkelerine uyduklarını kabul etmektedirler.

Çıkar Çatışması (Conflicts of Interest): Yazarlar tarafından herhangi bir çıkar çatışması beyan edilmemiştir.

Finansal Destek (Funding): Yazarlar, çalışmanın hazırlanması ve/veya yayınlanması sürecinde herhangi bir finansal destek almamışlardır.

Yazar Katkı Oranı (Author Contributions): Yazarlar, çalışmaya olan katkılarını şu şekilde beyan etmişlerdir: Kavramlaştırma ve çalışma dizaynı, V. Gürsel, C. O. Tuncel ve S. Geldimyradov; verilerin toplanması, V. Gürsel ve S. Geldimyradov; verilerin analizi ve sonuçların yorumlanması, V. Gürsel, C. O. Tuncel ve S. Geldimyradov; çalışmanın ilk/taslak halinin yazılması, V. Gürsel, C. O. Tuncel ve S. Geldimyradov; çalışmanın gözden geçirilmesi ve düzenlenmesi/düzeltilmesi, V. Gürsel ve C. O. Tuncel. Çalışmanın ilk ve son hali tüm yazarlar tarafından okunmuş ve onaylanmış olup, yazarlar çalışmalarıyla ilgili sorumluluğu kabul etmektedirler. 


\section{Son Notlar}

1. Üniversite öğrenimi öncesinde Bursa'da yaşayan öğrenciler BUÜ'de öğrenim görme fırsatına sahip olmasalardı başka bir şehirde öğrenim görecekler ve öğrenim süreleri boyunca Bursa dışında yaşayacaklardı. Bu nedenle söz konusu ögrenciler tarafından yapılan harcamalar da BUÜ kaynaklı harcama olarak hesaplamalara dâhil edilmiştir.

\section{Kaynaklar}

Acaroğlu, H., Kartal, Z., \& Güllü, M. (2017). Üniversitelerin bölgesel ekonomik kalkınma üzerindeki etkisi: Eskişehir'in Sivrihasar ilçesi üzerine bir araştırma. Anadolu International Conference in Economics, V, 11-13 Mayıs 2017, Eskişehir.

Atılgan Yaşa, A., \& Bakırtaş, D. (2020). Üniversite öğrencilerinin harcama analizi: Manisa-Salihli örneği. Insan ve Toplum Bilimleri Araştırmaları Dergisi, 9(3), 2237-2261.

Atik, H. (1999). Üniversitelerin yerel ekonomilere katkıları: Teori ve Erciyes Üniversitesi üzerinde bir uygulama. Erciyes Üniversitesi ikitsadi ve Idari Bilimler Fakültesi Dergisi, 15, 99-109.

Bayram, N. (2017). Sosyal bilimlerde SPSS ile veri analizi. Bursa: Ezgi Kitapevi.

Beşballı, S. G., \& Öztürk, Z. (2017). Artvin Çoruh Üniversitesi öğrencilerinin harcamalarının Artvin ekonomisine katkısı. Karadeniz Araştırmaları, XIV(56), 135-157.

Bursa Uludağ Üniversitesi, (2019). Bursa Uludağ Üniversitesi 2018 yılı idare faaliyet raporu. http://www.uludag.edu.tr/sgdb/default/konu/4829 (Erişim Tarihi: 15 Nisan 2019).

Çoban, M. N., \& Çoban, A. (2020). Suluova Meslek Yüksekokulu öğrencilerin Suluova ilçe ekonomisine katkıları. Tokat Gaziosmanpaşa Üniversitesi Sosyal Bilimler Araştırmaları Dergisi, Sonbahar Özel Sayısı, 74-82.

Demirelli, C., \& Taşkın, E. (2013). Üniversite öğrencilerinin bulundukları şehre ekonomik katkıları: Kütahya il merkezi örneği. Dumlupınar Üniversitesi Sosyal Bilimler Üniversitesi Dergisi, 37, 321-328.

Erdoğan, M., \& Karagöl, V. (2018). Bölgesel kalkınmada yeni kurulan üniversitelerin rölü: Bingöl örneği. Uluslararası Ekonomi, Işletme ve Politika Dergisi, 2(1), 51-78.

Glückler, J., Panitz, R., \& Wuttke, C. (2018). The economic impact of the universities in the state of Baden-Württemberg. (Ed.) P. Meusburger, M. Heffernan \& L. Suarsana, Geographies of the university (pp. 479-509). Cham: Springer.

Görkemli, H. N. (2009). Selçuk Üniversitesi'nin Konya kent ekonomisine etkileri. Selçuk Üniversitesi Sosyal Bilimler Enstitüsü Dergisi, 22, 169-186.

Görkemli, H. N. (2011). Üniversiteler ve kent ekonomisi (Selçuk Üniversitesi örnegi). Konya: Çizgi Kitapevi.

Gümüş, N., \& Ekiz, N. (2017). Üniversite öğrencilerinin tüketim harcamalarının şehir ekonomisine katkısının belirlenmesi: Kastamonu ilinde bir araştırma. Kastamonu Üniversitesi iktisadi ve idari Bilimler Fakültesi Dergisi, 17(3), 99-116.

Kalkan, H., Dilek, S., \& Kesgingöz, H. (2019). Kastamonu Üniversitesi'nin şehir ekonomisine katkısı. Üçüncü Sektör Sosyal Ekonomi Dergisi, 54(4), 1707-1725.

Kaşı, M., \& Serel, A. (2008). Üniversite öğrenci harcamalarının analizi ve bölge ekonomilerine katkılarını belirlemeye yönelik bir araştırma. Celal Bayal Ünivesitesi I.i.B.F Dergisi, 15(2), 99-100.

Koç, N. (2019). Üniversite öğrenci harcamalarının kent ekonomisine katkısı: Hitit Üniversitesi İktisadi ve İdari Bilimler Fakültesi öğrencileri üzerine bir analiz. Üçüncü Sektör Sosyal Ekonomi Dergisi, 54(1), 344-365.

Korkmaz, Ö. (2015). Üniversite öğrencilerinin harcamalarının il ekonomisine katkısı: Bayburt Üniversitesi İktisadi ve Idari Bilimler Fakültesi öğrencileri üzerinde bir analiz. Atatürk Üniversitesi İktisadi ve Idari Bilimler Dergisi, 29(2), 233250.

Kotosz, B., Guanard-Anderson, M., \& Lukovics, M. (2018). The local economic impact of universities: An international comparative analysis (France and Hungary). (Ed.) J. Ateljevic \& J. Budak, Entrepreneurship in post-communist countries (pp. 151-131). Cham: Springer

Lewis, J. A. (1986). Assessing the effect of the Polytechnic, Wolverhampton on the local community. Urban Studies, 25(1), 53-61.

Oxford Economics, (2016). The impact of University of Bath. Oxford. https://www.bath.ac.uk/publications/theeconomic-impact-of-the-university-of-bath/ (Erişim Tarihi: 20 Ocak 2019)

Özyakışır, D., \& Şayan, S. (2016). Üniversite öğrenci harcamalarının kent ekonomisine katkısı: Kafkas Üniversitesi üzerine bir saha çalışması. Kafkas Üniversitesi Sosyal Bilimler Ensititüsü Dergisi, Ek Sayı 1, 197-219. 
Pastor, J. M., Perez, F., \& de Guevara, J. F. (2013). Measuring the local economic impact of universities: An approach that considers uncertainty. Higher Education, 65(5), 539-564.

Saray, M. O., \& Çeker, K. (2018). Üniversitlerin şehir ekonomisine katkıları: İnönü Üniversitesi örneği. Çağdaş Yerel Yönetimler Dergisi, 27(4), 99-130.

Sarkım, M., Seker, F., Kurtoğlu, R., \& Kara, M. (2017). Bozok Üniversitesi'nde öğrenim gören öğrencilerin tüketim harcamları analizi ve Yozgat ekonomisine etkileri. Journal of Social and Humanities Sciences Research, 4(12), 1199-1213.

Selçuk, G. N. (2012). Atatürk Üniversitesi öğrenci harcamalarının analizi ve Erzurum ekonomisine katkısı. Atatürk Üniversitesi Sosyal Bilimler Enstitüsü Dergisi, 16(3), 317-330.

Sevüktekin, M., \& Çınar, M. (2014). Ekonometrik zaman serileri analizi. Bursa: Dora Yayınevi.

Tösten, R., Çenberlitaş, İ., \& Gökoğlan, K. (2013). Dicle Üniversitesi öğrencilerinin harcama analizi ve Diyarbakır ekonomisne katkısı. Dicle Üniversitesi Sosyal Bilimler Enstitüsü Dergisi, 5(10), 90-114.

Türkiye İstatistik Kurumu, (2020). İstatistik veri portalı. https://data.tuik.gov.tr/ (Erişim Tarihi: 24 Haziran 2020).

Uygun, M., Mete, S., Kara F., \& Bağcı, H. (2016). Üniversitenin kente olan ekonomik, sosyo-kültürel ve çevresel etkilerine yönelik yerel halk algısı. Aksaray Üniversitesi Iktisadi ve Idari Bilimler Fakültesi Dergisi, 8(4), 66-85.

Valero, A., \& Reenen, J. V. (2019). The economic impact of universities: Evidence from across the globe. Economics of Education Review, 68, 53-67.

Yayar, R., \& Demir, D. (2013). Gaziosmanpaşa Üniversitesi'nin Tokat ili ekonomisine katkısı. Akademik Araştırmalar ve Çalışmalar Dergisi, 5(8), 106-122.

Yayar, R., Şeker, H., \& Karanfil, N. (2018). Amasya Üniversitesi'nin il ekonomisine katkısı. Finans Politik \& Ekonomik Yorumlar, 55(635), 37-49.

Yükseköğretim Kurulu, (2021). Yüksek öğretim bilgi yönetimi sistemi. https://istatistik.yok.gov.tr/ (Erişim Tarihi: 19 Ocak 2021).

Zhang, Q., Larkin, C., \& Lucey, B. M. (2017). The economic impact of higher education institutions in Ireland: Evidence from disaggregated input-output tables. Studies in Higher Education, 42(9), 1601-1623. 


\section{EK: Çarpan Katsayısının Hesaplanması}

Zaman serisi verileri ile yapılan regresyon analizlerinde serilerin durağan dışı olması sahte regresyon sorununa yol açabilmektedir. Bu durumda regresyon analizden elde edilen sonuçlar gerçeği yansıtmayacaktır. Sahte regresyon sorunundan kaçınmak için iki yönteme başvurulabilir. Birincisi serileri durağanlaştırmak için farkların alınması, ikincisi ise eştümleşme analizidir. Fark alma işlemi uzun dönem ilişkiyi yok ettiğinden, uzun dönemli ilişkiyi ortaya koymak için eştümleşme analizine başvurmak gerekmektedir. Eştümleşme analizi için geliştirilen ilk test Engle-Granger testidir. Engle-Granger testi birkaç adımdan oluşmaktadır. İlk adımda birim kök testleri yardımıyla değişkenlerin tümleşme dereceleri bulunur. Değişkenlerin tümleşme dereceleri aynı ise değişkenler arası uzun dönem ilişkiyi gösteren eştümleştirici regresyon modeli en küçük kareler yöntemi ile tahmin edilir. Modelden elde edilen hata terimlerine birim kök testi uygulanır. Uygulanan test sonucu hata terimlerinin durağan olduğu belirlenirse değişkenler arasında eştümleşme ilişkisi olduğu sonucuna varılır (Sevüktekin ve Çınar, 2014: 561-564).

Bu çalışmada marjinal tüketim eğilimini hesaplamak amacıyla Tüik tarafından yayınlanan zincirlenmiş hacim cinsinden "yerleşik hanehalkları tüketimi" ve "hanehalkına hizmet eden kar amacı olmayan kuruluşların tüketimi" serilerinin toplanmasıyla oluşturulan zincirlenmiş hacim cinsinden tüketim harcamaları serisi (TÜKETIM) ile zincirlenmiş hacim cinsinden harcamalar yöntemiyle gayrisafi yurtiçi hasıla serisi (GSYH) arasında regresyon ilişkisi kurulmuştur. Kurulan ilişkide sahte regresyon sorunundan kaçınmak için EngleGranger eştümleşme yöntemine başvurulmuştur. Bu amaçla öncelikle GSYH ve TÜKETiM serilerine genişletilmiş Dickey-Fuller birim kök testleri uygulanarak birim kökün varlığı ve serilerin eştümleşme derecesi araştırılmıştır.

GSYH serisinin, birim kök sınaması yapmak üzere kullanılan modelde kesme ve trend olup olmadığı fark etmeksizin her üç anlamlılık düzeyinde de birim köke sahip olduğu tespit edilmiştir. GSYH serisinin birinci farkına birim kök testi uygulandığında kesmesiz ve trendsiz modelde $\% 10$, kesmeli ve trendsiz model ile kesmeli ve trendli modelde \%1 anlamlılık düzeyinde durağan olduğu belirlenmiştir. (Bkz. Ek Tablo 1)

TÜKETIM serisinin, kesmesiz ve trendsiz model ile kesmeli ve trendsiz modelde her üç anlamlılık düzeyinde birim köke sahip olduğu belirlenirken, kesmeli ve trendli modelde $\% 10$ anlamlılık düzeyinde durağan olduğu tespit edilmiştir. TÜKETiM serisinin birinci farkına birim kök testi uygulandığında kesmesiz ve trendsiz modelde \%10, kesmeli ve trendsiz model ile kesmeli ve trendli modelde \%1 anlamlılık düzeyinde durağan olduğu görülmüştür. (Bkz. Ek Tablo 1)

Ek Tablo 1. Birim Kök Testleri

\begin{tabular}{|c|c|c|c|c|c|c|}
\hline & \multicolumn{3}{|c|}{$\begin{array}{l}\text { Genişletilmiş Dickey Fuller test istatistiği } \\
\text { (düzey) }\end{array}$} & \multicolumn{3}{|c|}{$\begin{array}{l}\text { Genişletilmiş Dickey Fuller test istatistiği } \\
\text { (birinci fark) }\end{array}$} \\
\hline & $\begin{array}{l}\text { Kesmesiz } \\
\text { Trendsiz }\end{array}$ & $\begin{array}{l}\text { Kesmeli } \\
\text { Trendsiz }\end{array}$ & $\begin{array}{l}\text { Kesmeli ve } \\
\text { Trendli }\end{array}$ & $\begin{array}{l}\text { Kesmesiz } \\
\text { Trendsiz }\end{array}$ & $\begin{array}{l}\text { Kesmeli } \\
\text { Trendsiz }\end{array}$ & $\begin{array}{l}\text { Kesmeli ve } \\
\text { Trendli }\end{array}$ \\
\hline GSYH & 3,687648 & $-1,967426$ & $-1,720673$ & $-1,793434^{*}$ & $-4,485649^{* * *}$ & $-4,410060^{* * *}$ \\
\hline p değeri & 0,9999 & 0,2994 & 0,7224 & 0,0695 & 0,0009 & 0,0059 \\
\hline TÜKETIM & 2,337136 & $-1,514667$ & $-3,409344^{*}$ & $-1,744321^{*}$ & $-4,760471^{* * *}$ & $-5,009385^{* * *}$ \\
\hline p değeri & 0,9946 & 0,5160 & 0,0634 & 0,0769 & 0,0004 & 0,0012 \\
\hline
\end{tabular}

Ek Tablo 2'de TÜKETiM ve GSYH serileri arasında kurulan regresyon ilişkisinin sonuçları görülmektedir. Marjinal tüketim eğilimi $b_{1}=0,529$ olarak bulunmuştur. Gelirdeki 1 birimlik artış (azalış), özel tüketim harcamalarını 0,529 birim arttırmaktadır (azaltmaktadır). Keynesyen çarpan katsayısı ise [Çarpan = $1 /\left(1-b_{1}\right)$ ] eşitliği kullanılarak 2,12 olarak bulunmuştur. 
Ek Tablo 2. Regresyon Analizi

\begin{tabular}{|l|c|c|c|c|}
\hline \multicolumn{5}{|c|}{ Bağımlı değişken: TÜKETIM } \\
\hline \multicolumn{5}{|c|}{ Yöntem: En Küçük Kareler } \\
\hline \multicolumn{5}{|c|}{ Gözlem sayısı: 48 } \\
\hline Keğişken & Katsayı & Std. Hata & T-istatistiği & Olasılık değeri \\
\hline C & 27483941 & 3489233 & 7,876786 & 0,0000 \\
\hline GSYH & 0,529602 & 0,009752 & 54,30974 & 0,0000 \\
\hline \multicolumn{5}{|c|}{} \\
\hline Düzeltilmiş R-kare & 0,984310 & R-kare & 0,984644 \\
\hline F istatistik & 2949,548 & Durbin-Watson istatistiği & 1,093690 \\
\hline Prob (F istatistik) & 0,000000 & \\
\hline
\end{tabular}

Son olarak, TÜKETIM ve GSYH serileri arasında kurulan regresyonun kalıntılarına birim kök testi uygulanmıştır. Hesaplanan t değeri $(-4,32) \% 1, \% 5$ ve \%10 anlamlılık düzeyleri için MacKinnon tarafından sunulan kritik değerlerden daha küçük olduğundan sıfır hipotezi ret edilmektedir (Bkz. Ek Tablo 3). Sıfır hipotezinin ret edilmesi kalıntıların durağan olduğu, diğer bir ifadeyle GSYH ve TÜKETiM serilerinin eştümleşik olduğu anlamına gelmektedir. Bu durumda marjinal tüketim eğilimi katsayısının anlamlı olduğu anlaşılmaktadır. Başka bir ifade ile sahte regresyondan kaynaklanan bir ilişki olmadığı görülmektedir.

Ek Tablo 3. Hata Terimlerinin Birim Kök Testi

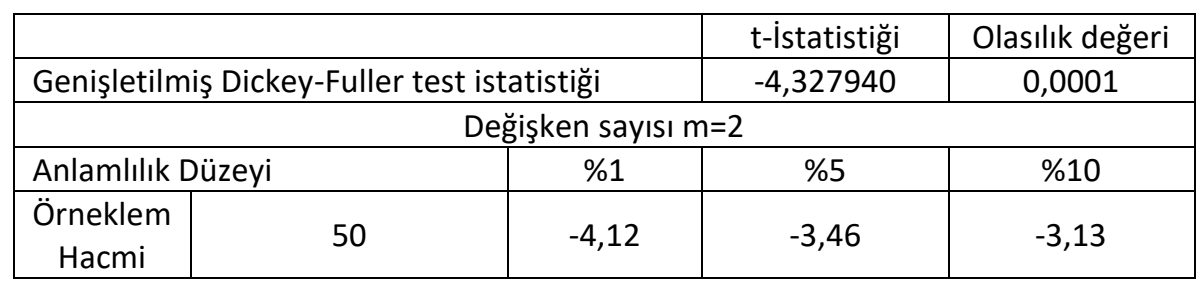

Kaynak: MacKinnon'dan aktaran, Sevüktekin ve Çınar, 2014:564. 
This Page Intentionally Left Blank 